\title{
フェムト秒レーザーによる微粒子を用いた極微細加工と生体応用
}

\author{
寺川 光洋 ${ }^{1,2}$, 石井 敦浩 ${ }^{2}$ \\ 1慶應義塾大学 理工学部電子工学科 ( ₹223-8522 神奈川県横浜市港北区日吉3-14-1) \\ 2慶應義塾大学大学院 理工学研究科総合デザイン工学専攻( テ223-8522 神奈川県横浜市港北区日吉3-14-1)
}

\section{Femtosecond Laser Nanoprocessing and Bio-Applications}

\author{
Mitsuhiro TERAKAWA ${ }^{1,2}$ and Atsuhiro ISHII ${ }^{2}$ \\ ${ }^{1}$ Department of Electronics and Electrical Engineering, Keio University 3-14-1 Hiyoshi, Kohoku, Yokohama, Kanagawa $223-8522$ \\ ${ }^{2}$ School of Integrated Design Engineering, Keio University 3-14-1 Hiyoshi, Kohoku, Yokohama, Kanagawa 223-8522
}

(Received July 26, 2016)

\begin{abstract}
The use of small particles has expanded the capability of ultrafast laser processing and provides precise processing in nanometer-scale space that overcomes the theoretical diffraction-limited spatial resolution. Recently precise laser processing is showing attractive developments in biomedical applications including drug delivery and cell stimulation. This review gives the fundamentals of laser processing by enhanced optical fields and its calculational studies. We also describe the recent progresses in bioapplications that use femtosecond lasers and small particles.
\end{abstract}

Key Words: Ultrafast laser processing, Nanoprocessing, FDTD, Bioapplication

1. はじめに

超短パルスレーザー加工に関係する研究者であれば誰 もが知っているであろうChichkovらによるフェムト秒 レーザーとナノ秒レーザーによるアブレーションを比較 した論文 ${ }^{1)}$ から既に20年が過ぎた。今日では，フェムト 秒レーザーを用いた加工は，金属はもちろんのこと，透 明材料を含む誘電体, 高分子材料, 生体組織, 細胞, と いったあらゆるものを対象とし, 基礎研究から産業応用 まで広く進められている。除去加工だけでなく, 付加 (additive) 加工も展開されており, 重合もしくは還元と いった相互作用を利用した造形法が知られている2,3).

生体組織もしくは細胞を対象としたフェムト秒レー ザープロセシングは，冒頭で述べた論文から時を経ずし て報告されている。例えば，1999年に細胞核内の染色体 をフェムト秒レーザーにより切断する論文が発表され た4)、細胞のレーザーアブレーションでは，培養細胞は 可視から近赤外域においてほぼ透明であることから，水 中に集光したフェムト秒レーザーが誘起する現象を基に 相互作用が議論されている5)。後述するように, 培養細 胞は軟らかいため集光点近傍に生じるプラズマ, キャビ テーション，衝撃波による影響を受けやすい.

フェムト秒レーザー加工では，ビームの空間強度分布 と加工しきい值の関係, 多光子過程による非線形相互作 用，等への着眼点により現在では $100 \mathrm{~nm}$ よりさい 解像度の加工が実現している。一般に，レーザー加工で
は回折限界により決定される集光径および周囲に生じる 熱影響層により加工解像度が決まる。サブミクロンから ナノスケールの微細加工は, 熱影響層が極めて小さい利 点を伴ってはじめて実現する。すなわち, フェムト秒 レーザー加工では，相互作用領域を小さくすることと加 工の微細さは直結するとも言える。著者らを含めいくつ かのグループは，回折限界を超えて相互作用領域を小さ くする方法のひとつとして, 微小構造近傍に生じる増強 光を利用した研究を行っている.

本稿では，回折限界を超えた微小領域に生じさせた高 強度光，すなわち局在増強光によるフェムト秒レーザー アブレーションとその光強度計算について述べ, 続いて その生体応用に関して報告事例を取り上げながら概説す る。また, 著者らが行っている誘電体粒子を用いた細胞 のアブレーションに関する研究について紹介する。

\section{2. 局在増強光によるレーザープロセシングと光強度計算}

金属微粒子もしくは誘電体微粒子にレーザーを照射す ると，微粒子近傍に近接場光が生じる。生じた非伝搬性 の光はナノスケールで局在し，その電界振幅は距離 $r^{-3}$ 乗 に比例して減衰するが，入射電界よりも数倍以上高い光 電界を局所領域に得ることができる，微粒子への光照射 により得られる散乱場はMie散乱理論により求められ, 粒子寸法と誘電率, 周囲の誘電率から粒子の散乱断面積 を計算することができる。微粒子近傍に生じる散乱場は 
微粒子内部の分極モードに依存し, 入射光の波長が共鳴 モードに対応しているときに散乱断面積のピークが得ら れる。金属微粒子では，レーザーが照射されると微粒子 表面の電子の集団振動, すなわちプラズモンが励起さ れ，金属微粒子周囲に新たな電磁界分布を誘起する。金 属微粒子ではこのプラズモン近接場光に加え, 加工対象 基板の鏡像電荷との結合による電界増強も寄与する.

局在増強光を加工に用いると, 回折限界よりも小さい 寸法の加工が可能となる. 局在増強近接場光は連続光や ナノ秒レーザー等の照射によっても当然生じるが，フェ ムト秒レーザーを用いると (1) 非熱的プロセスによる熱 影響層のほとんどない加工, および(2)ワイドバンド ギャップを持つ透明材料も非線形相互作用により加工可 能, といった特長を, 回折限界よりも小さい寸法で実現 できる．Fig. 1に，シリコン基板上に配置した直径 $200 \mathrm{~nm}$ の酸化チタン微粒子に波長 $400 \mathrm{~nm}$ のフェムト秒レー ザーを照射することにより得られたシリコン基板表面の 構造を示す。波長よりも大幅に小さい直径 $100 \mathrm{~nm}$ 以下 のナノホールが得られている。

微粒子に光を照射した際に生じる近接場はMie散乱理 論とMessingerらによる近接場効率により表すことがで きるが, 近年の計算機の発展に伴い, Maxwellの方程式 を時間的・空間的に差分化して逐次計算をする有限差分 時間領域 (Finite-Difference Time-Domain: FDTD) 法によ り, 微細構造周囲の電磁界強度分布を容易に求められる ようになっている。 三次元FDTD法では, 解析領域を空間 的に微小な単位セルに分割し，時間を離散化して座標を

$$
(x, y, z, t)=(i \Delta x, j \Delta y, k \Delta z, n \Delta t)
$$

の格子点に割り当てる. 電界は各辺の中心点にて辺に 沿って, 磁界は各面の中心点にて面に垂直に与えられ る.ファラデーの法則とアンペールの法則を基本方程式

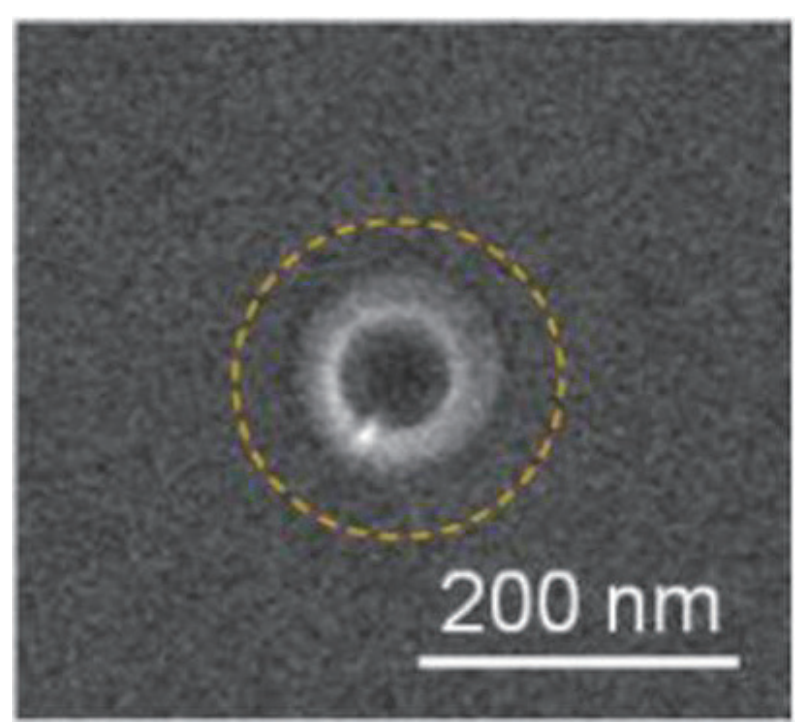

Fig. 1 SEM image of fabricated nanohole by using amorphous $\mathrm{TiO}_{2}$ particle with the irradiation of $400 \mathrm{~nm}$ femtosecond laser. Dashed circle indicates the size of the particle.
とし, 逐次計算することで電磁界を求める. Fig. 2は, シリコン基板上に配置した直径 $200 \mathrm{~nm}$ の酸化チタン微 粒子に波長 $400 \mathrm{~nm}$ の平面波を照射した際に発生する局 在増強光をFDTD法により求めたものである.

このように，微小構造にレーザーを照射することによ り生じる光増強度およびその分布はFDTDにより求める ことができるものの，この計算には非線形相互作用は含 まれていない, すなわち, 多光子吸収, トンネルイオン 化，等，超短パルスレーザーアブレーションにおいて顕 著となる現象は含まれていない。実験により得られるナ ノホールの直径と計算により求められる光増強領域の直 径は近い值となるものの, ナノホールの深さは計算值に より求められる侵入長と差が生じる.

\section{3. ナノ粒子を使った細胞膜プロセシング}

微粒子へのレーザー照射により生じる光増強場は，大 面積への一様照射により複数の微粒子近傍に同時多発的 に微小相互作用領域を得られる。このため, レンズを用 いた伝搬光の集光による単一細胞処理とは異なり，複数 の細胞を同時に処理できる。多くの関連報告例では生 体・細胞における線形吸収が小さい近赤外の波長が使用 されている。すなわち，微粒子と接触もしくは結合され た細胞のみ，微粒子近傍に生じる非線形相互作用によっ て処理できる，例えば，ドイッの研究グループは，金微 粒子へのフェムト秒もしくはピコ秒レーザー照射により 細胞膜に小孔を形成し，プラスミドDNAを細胞内に導 入できることを示した ${ }^{7-10)}$ 。また，カナダのMeunierらの グループも同様に金微粒子へのフェムト秒レーザー照射 による細胞への外来分子導入を行っている ${ }^{11-13)}$. 最近で は, この方法は細胞膜への小孔形成だけではなく, 細胞 刺激への展開もみせている ${ }^{14,15)}$.

こうした細胞プロセシングでは，上述した局在増強光 による加工とほほ同様の方法であるものの，液体中にて 実施していることが特徴である。また，プロセシングの

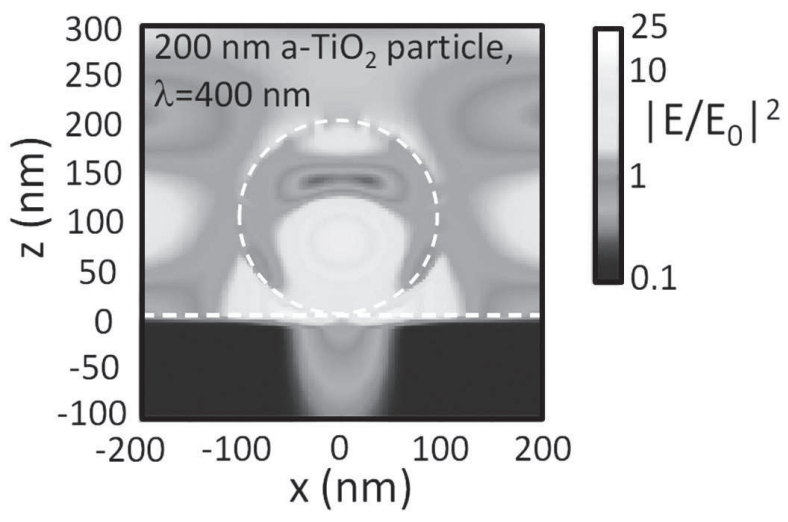

Fig. 2 Optical intensity distribution in the vicinity of 200 $\mathrm{nm} \mathrm{TiO}_{2}$ particle on $\mathrm{Si}$ substrate simulated by 3D FDTD method. A linearly polarized $400 \mathrm{~nm}$ plane wave is illuminated to the particle with wave vector in $\mathrm{z}$ direction. Dashed circle indicates lineation of the particle. ${ }^{6}$ ) 
対象が極めて軟らかいため, 容易に変形や損傷等が生じ る.このため, 集光点におけるアブレーションだけでな く，発生する衝撃波等による影響も大きい，金ナノ粒子 を用いたフェムト秒レーザーによる細胞膜プロセシング では，流体力学等を水中に適用する理論計算が報告され ている. Meunierらは, 水中の金ナノ粒子にフェムト秒 レーザーを照射した際に生じる衝撃波およびキャビテー ションバブルの理論計算を行っている ${ }^{16-18)}$. 近赤外フェ ムト秒レーザーを照射した際に生じる近接場光, プラズ マ生成から粒子周囲の水分子へのエネルギー伝達, 衝撃 波とキャビテーションバブルの影響を理論的に統合モデ ルとして計算し，実験結果と比較した。直径 $100 \mathrm{~nm}$ の 金ナノ粒子に非共鳴波長 $800 \mathrm{~nm}$ のフェムト秒レーザー を照射すると, 発生するプラズマの電子密度は最大 $4 \times 10^{22} \mathrm{~cm}^{-3} に$ 達し，プラズマは粒子表面からわずか $30 \mathrm{~nm}$ の範囲に閉じ达められる。衝撃波の最大圧力はお よそ80 GPaに達するが, 粒子中心から $200 \mathrm{~nm}$ 伝搬した位 置の圧力は $1 \mathrm{GPa}$ まで低下することを状態方程式から説 明した ${ }^{15)}$ 。また, 生成するキャビテーションバブルの最 大平均直径がレーザー照射から $72 \mathrm{~ns}$ 経過後に $1.2 \mu \mathrm{m}$ とな ることを計算より求め, さらに実験結果ではレーザー照 射から $80 \mathrm{~ns}$ 経過後に813 nmとなることを述べている。

\section{4. 生分解性ポリマー粒子を使った細胞膜プロセシング}

我々は, 光増強場を得るための粒子として生分解性ポ リマーを用いた研究を行っている ${ }^{19-21)}$. 生分解性ポリ マーは生体内において無毒な成分に分解されて代謝もし くは吸収されるため, 生体適合性と安全性に優れる。

Fig. 3に, 方法の概念図を示す。細胞膜に生分解性ポリ マーの微粒子を結合し，フェムト秒レーザー照射により 微粒子下に光増強場を発生させる. 細胞と細胞膜は波長 $800 \mathrm{~nm}$ の線形吸収は小さく, 粒子下の集光点において局 所的に非線形相互作用を生じさせ，細胞膜を局所的に穿 孔する，実験では，粒子にポリ乳酸 (Poly Lactic Acid: PLA) もしくは乳酸グリコール酸共重合体 (Poly Lactic co-Glycolic Acid: PLGA) を用いた，PLAは生体適合性に 優れていることから, 既に一部の医療用途に実用化され ている，また，PLGAは組成比率により分解速度を制御 することが可能である. Fig. 4に, FDTD法により求めた 直径 $2 \mu \mathrm{m}$ のLA粒子およびPLGA粒子によって得られる 光増強度分布を示す。文射光は波長 $800 \mathrm{~nm}$ の直線偏光 とした.PLAとPLGAの屈折率はそれぞれ 1.45 と 1.60 と し, 水中 (屈折率1.33)に配置した系の計算を行った. 光 強度の最大值はいずれも粒子より少し離れた位置に得ら れ，粒子直径が波長より大きいことから，近接場光より 実効焦点距離が長い伝搬光が主体の光増強場であること がわかる.こうした光強度分布は最近photonic jetと呼ば れることも多い.

平均直径 $2 \mu \mathrm{m}$ のPA粒子およびPLGA粒子を用いて, 浮遊状態の細胞に蛍光分子を導入した実験結果をFig. 5

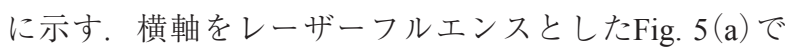
は, PLGA粒子の方が高い細胞内輸送効率(照射領域内

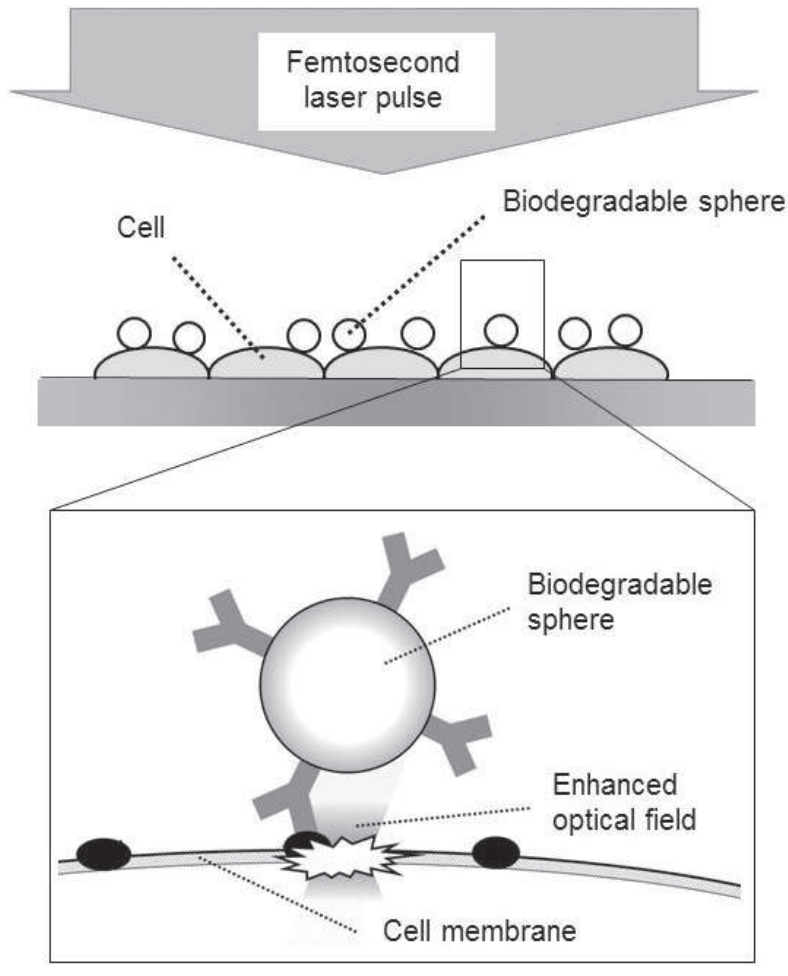

Fig. 3 Conceptual diagram of biodegradable microsphere-mediated cell perforation using femtosecond laser.
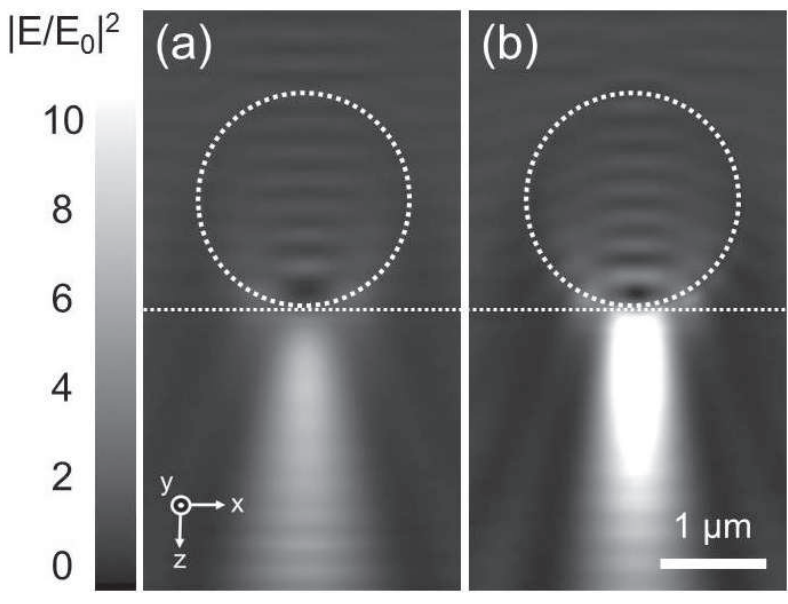

Fig. 4 Optical field distributions on the xz plane simulated by the 3D FDTD method for (a) PLA microsphere and (b) PLGA microsphere of $2 \mu \mathrm{m}$ diameter.

の細胞のうち，蛍光分子が細胞内に取り込まれた細胞の 割合)を示した。ただし，Fig. 4に示したように，粒子下 に得られる最大光強度は粒子屈折率により異なり, PLGA粒子の方がPLAよりも増強度が高い. FDTDによ り求めた粒子下における最大光強度を横軸として, 得ら れた細胞内輸送効率を正規化した結果をFig. 5(b)に示 す. 細胞内輸送効率は, 光増強場における最大光強度に 依存していることがわかる.

PLAとPLGAの比較では粒子下の最大増強度のみによ り議論を行ったが, 最近, 光増強場の光強度分布, 特に 


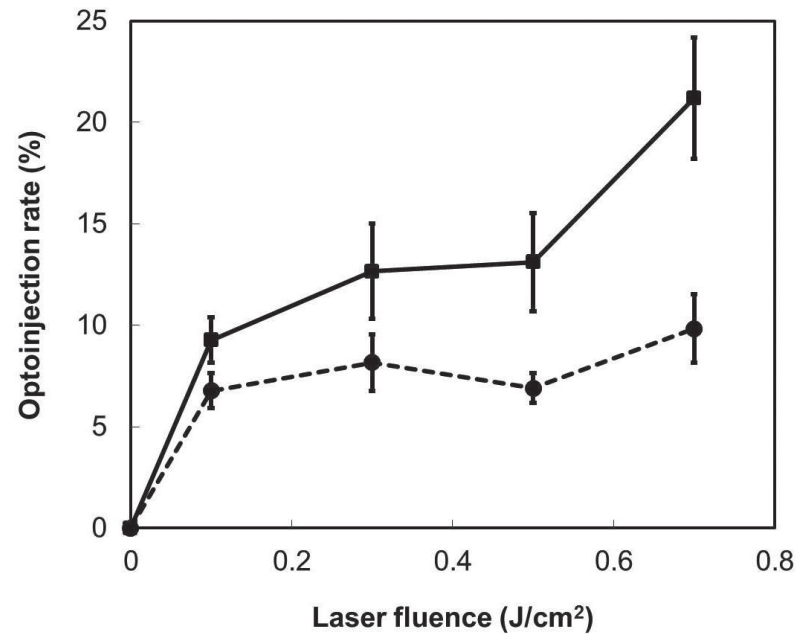

(a)

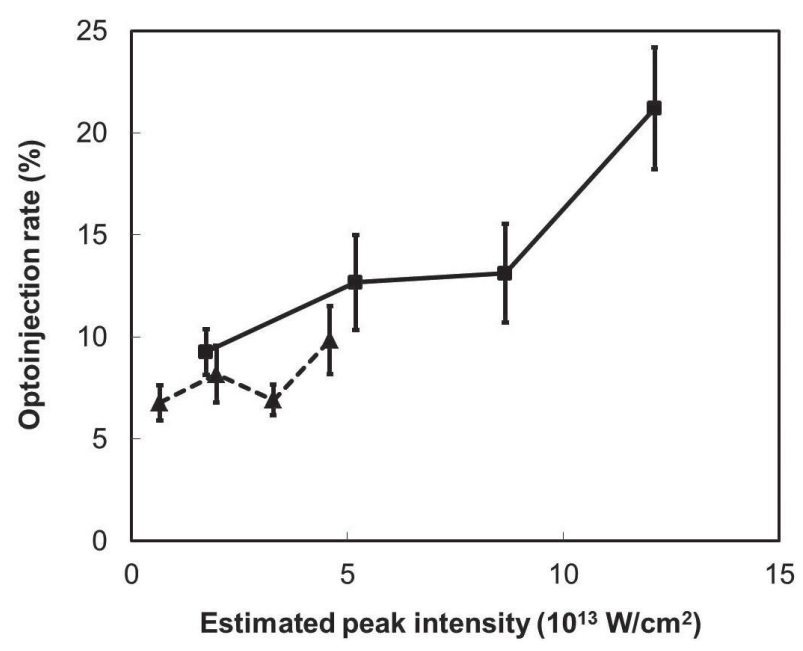

(b)

Fig. 5 Optoinjection ratios to cells in relation to (a) laser fluence and (b) estimated optical peak intensity under the microspheres calculated by FDTD method. Dashed lines and solid lines indicate results with PLA microspheres and PLGA microspheres, respectively. ${ }^{21}$

粒子と集光点の距離の違いを利用できないか, 試みてい る. Fig. 6 に, 直径 $0.75 \mu \mathrm{m}$ と $3.0 \mu \mathrm{m}$ のポリスチレン粒子下 の光強度分布を示す. 直径 $0.75 \mu \mathrm{m}$ の粒子ではレーザー フルエンス $0.7 \mathrm{~J} / \mathrm{cm}^{2}$, 直径 $3.0 \mu \mathrm{m}$ の粒子では $0.081 \mathrm{~J} / \mathrm{cm}^{2}$ とし, 粒子下における増強されたピーク強度が同じとな るようにした。この条件において実験を行ったところ， ピーク強度が同一であっても, 粒子径により細胞核内導 入効率が異なった。この結果から, 細胞内における相互 作用領域を変化させ，異なる効果を得られるのではない かと期待している。

\section{5. おわりに}

微粒子へのフェムト秒レーザー照射により励起される 光増強場を用いた加工について, その基礎から加工の特 徵, 光強度分布を求めるためのFDTD法について概説

\section{Estimated peak intensity $\left(10^{12} \mathrm{~W} / \mathrm{cm}^{2}\right)$}

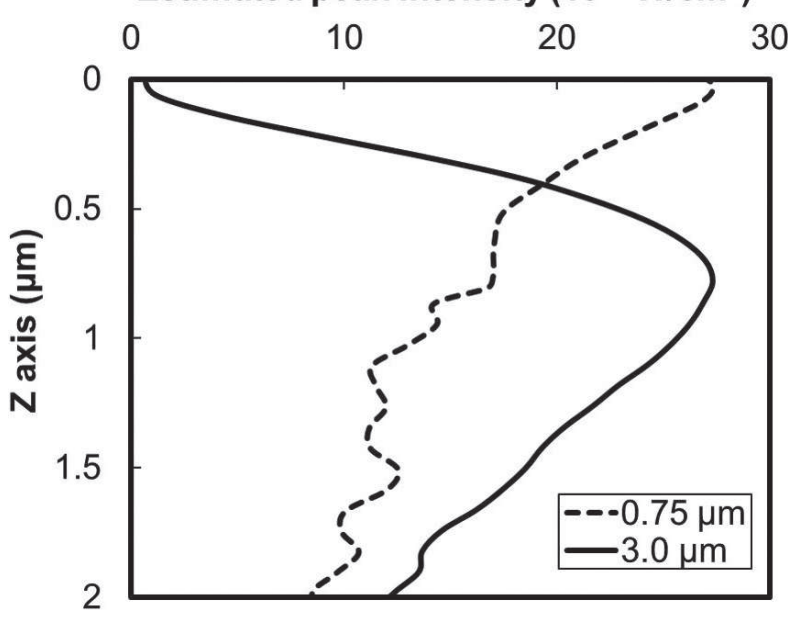

Fig. 6 Estimated optical intensity under polystyrene microspheres of $3 \mu \mathrm{m}$ (solid line) and $0.75 \mu \mathrm{m}$ (dashed line) in diameters along the $\mathrm{Z}$-axis under the spheres.

し, 細胞プロセシングへの応用および計算の報告事例を 紹介した。 ナノスケールの構造への光照射により生じる 光増強およびその強度分布は計算により容易に求められ る. 熱影響層が極めて小さいフェムト秒レーザー加工で は, 計算により求められる光強度分布と相互作用領域は 近い関係を示すものの, FDTD法は加工が開始される前 段階までの光の挙動を求めるため, 非線形相互作用は含 まれていない.このため固体材料のレーザーアブレー ションでは, 特に深さ方向において, 計算上の光増強場 のアスペクト比と加工の深さに違いが生じる．最大光強 度に加えその分布の違いを利用した研究はまだ端緒が開 けたばかりであるものの, 細胞操作および細胞内標的化 だけでなく，透明材料も対象として今後の研究の展開が 期待できる。

謝 辞

局在増強光に関して多大なるご助言を頂きました慶應 義塾大学名誉教授小原 實先生に心より感謝いたしま す。また, 研究を進めたNikolay Nedyalkov博士(ブルガ リア科学アカデミー), 田中悠人博士(現・トヨタ自動 車株式会社), 三橋 龍樹氏(現・東京ガス株式会社)に感 謝いたします。

本研究の一部は，科研費(26560263)の助成を受けて実 施されました。

\section{参考文献}

1) B. N. Chichkov, C. Momma, S. Nolte, F. V. Alvensleben, and A. Tünnermann: Appl. Phys. A 63 (1996) 109.

2) 丸尾昭二：Optronics 5 (2016) 132 (in Japanese).

3) T. Baldacchini edited: Three-Dimensional Microfabrication using Two-Photon Polymerization (Elsevier, Oxford, 2016).

4) K. König, I. Riemann, P. Fischer, and K. J. Halbhuber: Cell. Mol. Biol. 45 (1999) 195.

5) A. Vogel, J. Noack, G. Hüttman, and G. Paltauf: Appl. Phys. B 81 
(2005) 1015.

6) Y. Tanaka, G. Obara, A. Zenidaka, N. N. Nedyalkov, M. Terakawa, and M. Obara: Opt. Express 18 (2010) 27226.

7) M. Schomaker, J. Baumgart, A. Ngezahayo, J. Bullerdiek, I. Nolte, H. M. Escobar, H. Lubatschowski, and A. Heisterkamp: Proc. SPIE 7192 (2009) 71920U.

8) D. Heinemann, M. Schomaker, S. Kallies, M. Schieck, R. Carlson, H. M. Escobar, T. Ripken, H. Meyer, and A. Heisterkamp: PLoS ONE 3 (2013) e 58604.

9) S. Kalies, T. Birr, D. Heinemann, M. Schomaker, T. Ripken, A. Heisterkamp, and H. Meyer: J. Biophotonics 7 (2014) 474.

10) D. Heinemann, S. Kalies, M. Schomaker, W. Ertmer, H. Murua-Escobar, H. Meyer, and T. Ripken: Nanotechnology 24 (2014) 24501.

11) J. Baumgart, L. Humbert, E. Boulais, R. Lachaine, J. Lebrun, and M. Meunier: Biomaterials 33 (2012) 2345.

12) E. Bergeron, C. Boutopoulos, R. Martel, A. Torres, C. Rodriguez, J. Niskanen, J. Lebrun, F. M. Winnik, P. Sapieha, and M. Meunier: Nanoscale 7 (2015) 17836.

13) C. Boutopoulos, E. Bergeron, and M. Meunier: J. Biophotonics 9
(2016) 26.

14) S. Kalies, G. C. Antonopoulos, M. S. Rakoski, D. Heinemann, M. Schomaker, T. Ripken, and H. Meyer: PLoS ONE 10 (2015) e0124052.

15) S. Kalies, S. Keil, S. Sender, S. C. Hammer, G. C. Antonopoulos, M. Schomaker, T. Ripken, H. M. Escobar, H. Meyer, and D. Heinemann: J. Biomed. Opt. 20 (2015) 115005.

16) E. Boulais, R. Lachaine, A. Hatef, and M. Munier: J. Photochem. Photobiol. C-Photochem. Rev. 17 (2013) 26.

17) E. Boulais, R. Lachaine, and M. Munier: Nano Lett. 12 (2012) 4763.

18) R. Lachaine, E. Boulais, and M. Meunier: ACS Photonics 1 (2014) 331

19) M. Terakawa, Y. Tsunoi, and T. Mitsuhashi: Int. J. Nanomed. 7 (2012) 2653.

20) T. Mitsuhashi and M. Terakawa: J. Biomed. Opt. 19 (2014) 015003.

21) A. Ishii, K. Ariyasu, T. Mitsuhashi, D. Heinemann, A. Heisterkamp, and M. Terakawa: J. Biomed. Opt. 21 (2016) 055001. 